\title{
EDUKASI DAN PENYULUHAN MENGGUNAKAN MASKER YANG BAIK DAN BENAR DALAM MENGHADAPI COVID-19 MELALUI PEMBAGIAN MASKER DI DESA GELANGGANG LOMBOK TIMUR
}

\author{
ZINNURAIN, MUHAMAD SUHARDI \\ Fakultas Ilmu Pendidikan dan Psikologi Universitas Pendidikan Mandalika \\ email: zinnurain@undikma.ac.id
}

\begin{abstract}
ABSTRAK
Kondisi dunia global saat ini dihadapkan pada situasi yang mencekam dan darurat. Hingga pertengahan tahun 2021, seluruh negara di penjuru dunia termasuk Indonesia berkonsentrasi dalam upaya menanggulangi penyebaran wabah covid-19. Hal ini dikarenakan penyebaran covid-19 yang secara cepat semakin sulit terkontrol melebihi kecepatan petugas dalam upaya memutus rantai penyebaran. Berdasarkan observasi yang dilakukan di periode awal pandemi, masyarakat di kawasan Desa Gelanggang Kecamatan Sakra Timur Kabupaten Lombok Timur sebagian besar belum mendapat informasi dan pengetahuan mengenai bahaya covid-19. Hal ini menjadi dasar kurangnya kesadaran masyarakat dalam menggunakan masker sebagai bagian dari protokol kesehatan yang ditentukan pemerintah. Oleh karena itu, kegiatan pengabdian kepada masyarakat ini dilakukan dengan tujuan memberikan edukasi dan penyuluhan pentingnya menggunakan masker yang baik dan benar dalam menghadapi covid19 melalui pembagian masker di desa gelanggang lombok timur. Adapun metode yang digunakan dalam kegiatan ini adalah berupa edukasi dan penyuluhan kepada masyarakat cara menggunakan masker yang baik dan benar serta pembagian masker secara gratis sebagai alat protokol kesehatan. Hasil dari kegiatan ini yakni masyarakat di desa Gelanggang Kecamatan Sakra Timur Kabupaten Lombok Timur menjadi paham dan mengerti bahaya ancaman covid19 dan memahami langkah-langkah protokol kesehatan yang dilakukan sebagai upaya pencegahan penyebaran covid-19 berupa penggunakan masker yang baik dan benar.
\end{abstract}

Kata Kunci: edukasi dan penyuluhan, menggunakan masker, covid-19.

\section{PENDAHULUAN}

Kondisi dunia global saat ini dihadapkan pada situasi yang mencekam dan darurat. Pada Desember 2019 dunia digemparkan dengan mewabahnya sebuah penyakit radang paru (pneumonia), di Kota Wuhan, Provinsi Hubei, Cina, yang merenggut lebih dari empat ribu korban meninggal dunia. Setelah dilakukan penelitian, penyakit radang paru (pneumonia) tersebut disebabkan oleh virus corona (coronavirus). Virus corona merupakan keluarga besar viru yang sudah lama dikenal di dunia. Namun, virus tersebut biasa ditemukan pada hewan, seperti kucing, anjing, babi, sapi, kalkun, ayam, tikus, kelinci, dan kelelawar. Dinamakan corona karena virus ini memiliki duri-duri menyerupai mahkota (crown) (Sembiring, dkk, 2020).

Hingga pertengahan tahun 2021, seluruh negara di penjuru dunia termasuk Indonesia berkonsentrasi dalam upaya menanggulangi penyeberan wabah covid-19. Hal ini dikarenakan penyebaran covid-19 yang secara cepat semakin sulit terkontrol melebihi kecepatan petugas dalam upaya memutus rantai penyebaran. Berdasarkan definisi yang dirilis oleh WHO (World Health Organization) Coronovirus Disease 2019 (Covid-19) adalah penyakit menular yang disebabkan oleh Severe Acute Respiratory Syndrome Coronavirus 2 (SARS-CoV-2). SARSCov-2 merupakan corona virus jenis baru yang baru diidentifikasi sebelumnya pada manusia (Heldavidson, 2020). Berdasarkan data rilis WHO Virus jenis baru ini pertama kali terdeteksi di Kota Wuhan Provinsi Hubei Cina. Covid -19 akan mengalami penyakit pernapasan ringan hingga sedang dan sembuh tanpa memerlukan perawatan khusus. Penyakit ini sangat rentan pada lansia, dan mereka yang memiliki masalah medis mendasar seperti diabetes, penyakit pernapasan kronis, dan kanker memiliki kemungkinan terjangkit secara cepat. Transmisi 
Virus Covid-19 menyebar melalui tetesan air liur atau keluar dari hidung ketika orang yang terinfeksi batuk atau bersin.

Penderita yang terinfeksi virus Covid-19 akan mengalami gejala yang direspon berbeda oleh tubuh penderita. Respon gejala penderita yang terpapar covid-19 akan mengalami gejala mulai dari gejala ringan, sedang hingga berat. Adapun gejala yang paling umum dirasakan oleh penderita adalah mulai dari demam, batuk kering, hingga kelelahan. Gejala yang sedikit tidak umum dialami oleh penderita yakni rasa tidak nyaman dan nyeri, nyeri tenggorokan, diare, konjungitivitis, sakit kepala, hilangnya indera perasa atau penciuman, ruam pada kulit, atau perubahan warna pada jari tangan atau kaki (Marzuki, dkk, 2021: 16). Perkembangan penyebaran virus covid-19 terus berlangsung dan terjadi tidak hanya di China melainkan menyebar secara ekstensif ke seluruh dunia termasuk salah satunya di Indonesia. Dengan total kematian yang banyak dan membahayakan negara, tertanggal 30 Januari 2020 melalui World Health Organization (WHO) menetapkan wabah Corona Virus Disease 2019 atau yang dikenal dengan covid-19 sebagai suatu kedaruratan kesehatan masyarakat yang meresahkan dunia dan tepat 11 Maret 2020 wabah dinyatakan sebagai pandemi (WHO, 2021).

Berdasarkan data update resmi kasus Covid-19 yang bersumber dari website resmi pemerintah provinsi Nusa Tenggara Barat (pemprov NTB) dengan sumber resmi dinas kesehatan (Dikes) NTB disebutkan bahwa sampai dengan bulan Juli 2021 total kasus Pandemi Covid-19 yang terjadi di NTB mencapai total 15.027 kasus dengan rincian kasus total yang dirawat 766 (5.10\%), total yang sembuh 13.643 (90.79\%), dan total kasus kematian berjumlah 618 (4.11\%) (Dikkes NTB, 2021).

Perlindungan bagi segenap rakyat Indonesia baik dari segi medis maupun perlindungan dari segi hukum adalah merupakan bagian dari cita-cita bangsa Indonesia. Hal itu tercantum jelas dalam Pembukaan Undang-undang Dasar 1945. Tujuan nasional yang dimaksudkan tersebut yakni melindungi segenap bangsa Indonesia dan seluruh tumpah darah Indonesia, memajukan kesejahteraan umum, mencerdaskan kehidupan bangsa dan ikut melaksanakan ketertiban dunia yang berdasarkan kemerdekaan perdamaian abadi serta keadilan sosial (Agustina, 2016). Oleh karena itu, sebagai pengemban amanat untuk menyejahterakan masyarakat maka pemerintah berkewajiban untuk menghormati, melindungi dan memenuhi hak-hak asasi kesehatan tersebut. Kewajiban menghormati itu seperti menciptakan persamaan akses pelayanan kesehatan, pencegahan dari tindakan-tindakan yang dapat menurunkan status kesehatan baik masyarakat umum maupun tenaga tenaga kesehatan. Upaya pencegahan covid-19 dilakukan pemerintah melalui Kementerian Kesehatan dengan menginstruksikan kesadaran dan kepatuhan dalam penggunaan masker ketika di luar rumah.

Upaya pencegahan terhadap peningkatan jumlah penderita dan penyebaran Covid-19 yang semakin masive, maka perlu adanya langkah konkret seperti yang sudah ditetapkan oleh WHO pada bulan Maret 2020 yang menyatakan bahwa semua negara didesak untuk melakukan langkah-langkah efektif untuk mengurangi penularan (Lim, et al., 2020). Penyebaran pada masyarakat pun dapat dikurangi salah satunya dengan menjaga kebersihan tangan secara rutin dan upaya penggunaan masker yang baik dan benar sesuai standar yang ditentukan (Greenhalgh, et al., 2020). Hal ini perlu dilakukan karena Covid-19 dapat dengan mudah ditularkan melalui jalur pernapasan (tetesan dari orang yang terinfeksi, melalui batuk atau bersin) dan melalui kontak dengan permukaan yang terkontaminasi (Suhartati, dkk, 2020). Salah satu anjuran WHO untuk menggunakan masker dalam menekan penyebaran virus ini pun membuat masker yang umumnya digunakan dalam kegiatan medis menjadi sulit untuk didapatkan dan harganya pun menjadi mahal. Oleh karena itu, pada tanggal 1 April 2020 Kemenparekraf telah mengajak seluruh lapisan masyarakat untuk berpartisipasi dalam Gerakan Masker Kain dengan tujuan mendukung usaha pencegahan penyebaran wabah Covid19 (Utami, 2020).

Berdasarkan protokol kesehatan yang dikeluarkan oleh WHO, pemerintah menginstruksikan kepada masyarakat agar selalu mencuci tangan dengan menggunakan sabun 
pada air yang mengalir, dan selalu mengenakan masker pada saat berada di luar rumah (Sii, dkk, 2020). Kemenkes (2020:2) memaparkan bahwa penyakit ini dapat menyebar melalui tetesan kecil (droplet) dari hidung atau mulut pada saat batuk atau bersin. Droplet tersebut kemudian jatuh pada benda disekitarnya. Kemudian jika ada orang lain menyentuh benda yang sudah terkontaminasi dengan droplet tersebut, lalu orang itu menyentuh mata, hidung atau mulut (segitiga wajah), maka orang itu dapat terinfeksi Covid-19. Atau bisa juga seseorang terinfeksi Covid-19 ketika tanpa sengaja menghirup droplet dari penderita.

Berdasarkan observasi di awal waktu pandemi, masyarakat di sekitar Desa Gelanggang Kecamatan Sakra Timur Kabupaten Lombok Timur, belum sepenuhnya memahami langkah pencegahan covid-19 dan tidak semua masyarakat menggunakan masker. Masyarakat sekitar tidak seluruhnya memahami betapa pentingnya menggunakan masker sebagai upaya preventif terhadap covid-19. Oleh karena itu, dilakukan kegiatan pengabdian kepada masyarakat melalui edukasi dan penyuluhan kepada masyarakat cara menggunakan masker yang baik dan benar serta pembagian masker secara gratis sebagai alat protokol kesehatan sebagai bentuk dukungan terhadap pemerintah dalam melakukan pencegahan penularan COVID-19. Dengan adanya kegiatan pengabdian kepada masyarakat ini diharapkan warga dapat memahami cara pencegahan covid-19 dan menerapkannya, salah satunya adalah dengan disiplin menggunakan masker, sehingga bisa berkontribusi dalam pencegahan covid19 khususnya di wilayah wilayah Desa Gelanggang Kecamatan Sakra Timur Kabupaten Lombok Timur.

Tujuan pengabdian masyarakat yang berjudul edukasi dan penyuluhan menggunakan masker yang baik dan benar dalam menghadapi Covid-19 melalui pembagian masker di desa Gelanggang Lombok Timur ini adalah supaya masyarakat di desa Gelanggang Kecamatan Sakra Timur Kabupaten Lombok Timur semakin menyadari dan memahami bahwa pentingnya menggunakan masker sebagai tindakan protokol kesehatan di masa pandemi ini, terutama saat berada di luar rumah dan berinteraksi dengan banyak orang untuk menekan angka penyebaran virus corona dan penularan covid-19.

\section{Solusi Permasalahan Mitra}

Sebagai salah satu wilayah yang cukup jauh dari ibu kota provinsi dan berada pada bagian sisi tenggara pulau Lombok, masyarakat desa Gelanggang rata-rata memiliki tingkat kesadaran dan pemahaman mengenai covid-19 yang masih rendah. Oleh karena itu, edukasi dan penyuluhan yang dilakukan diharapkan mampu menyadarkan masyarakat secara lebih luas tentang pentingnya menjaga protokol kesehatan berupa penggunaan masker yang baik dan benar serta sesuai standar yang ditetapkan.

\section{METODE PENELITIAN}

Pelaksanaan kegiatan pengabdian kepada masyarakat dengan tema "edukasi dan penyuluhan menggunakan masker yang baik dan benar dalam menghadapi Covid-19 melalui pembagian masker di desa Gelanggang Lombok Timur" ini diawali dengan observasi kemudian selanjutnya dilakukan rapat kordinasi antara tim kegiatan pengabdian kepada masyarakat dengan pihak pemerintah desa Gelanggang Kecamatan Sakra Timur kabupaten Lombok Timur untuk selanjutnya meminta ijin untuk melakukan kegiatan pengabdian kepada masyarakat di wilayah desa Gelanggang.

Pelaksanaan kegiatan pengabdian kepada masyarakat dilakukan berlokasi di Desa Gelanggang Kecamatan Sakra Timur kabupaten Lombok Timur. Kegiatan dilakukan pada tanggal 14 Juni 2021 yang dihadiri oleh segenap Kepala Desa Gelanggang, Babinkamtibmas desa Gelanggang, BPD desa Gelanggang, Kepala Dusun se-desa Gelanggang dan perwakilan warga desa Gelanggang. Kegiatan dilakukan secara marathon dengan menyisir rumah warga di desa Gelanggang untuk selanjutnya memberikan edukasi sekaligus membagikan masker kepada warga masyarakat. 


\section{HASIL DAN PEMBAHASAN}

Hasil

Secara keseluruhan kegiatan berjalandengan baik sesuai dengan perencanaan. Semua pihak dapat bekerjasama dengan baik. Masker kesehatan yang disediakan sebanyak lebih kurang 500 pcs, habis tanpa ada sisa. Seluruh warga masyarakat yang disisir memperoleh masker. Para warga merasa sangat senang, karena mereka tidak perlu merogoh kantong untuk membeli masker.

\section{Pembahasan}

Dalam kegiatan pengabdian kepada masyarakat ini, dilakukanlah 5 tahapan untuk mencapai tujuan yang diharapkan, yaitu:

Observasi

Kegiatan observasi dan survey adalah langkah awal untuk rencana pengabdian yang sudah disepakati dengan tim, untuk di komunikasikan dengan mitra. Observasi ini menentukan apakah rencana pengabdian dapat terlaksana sesuai dengan rencana awal ataukah ada sedikit modifikasi bentuk dan tema yang akan dilaksanakan sesuai dengan kondisi real mitra yang dituju, dalam hal ini yang menjadi mitra pengabdian adalah Desa Gelanggang Kecamatan Sakra Timur Kabupaten Lombok Timur.

\section{Identifikasi masalah}

Pelaksanaan kegiatan identifikasi ini dilakukan dengan langsung datang berkunjung ke wilayah desa Gelanggang untuk mmelakukan wawancara dan bertanya langsung kepada pemerintah desa dalam hal ini kepala desa Gelanggang dan perwakilan masyarakat terkait permasalahan yang ada. Dengan komunikasi yang baik pihak kepala desa Gelanggang dan perwakilan masyarakat dapat terbuka menjelaskan masalah yang dihadapi dalam mengedukasi dan memberikan pemahaman mengenai pandemic covid-19 kepada masyarakat. Berdasarkan hasil identifikasi masalah yang dihadapai oleh desa adalah minimnya pengetahuan dan pemahaman warga mengenai ancaman bahaya penyebaran covid-19. Langkah yang dilakukan oleh pihak pemerintah desa masih sebatas memberikan anjuran dan sosialisasi terbatas dan belum sampai pada tahap melaksanakan pembagian masker secara gratis. Berdasarkan hasil identifikasi masalah ini, maka diketahui bahwa masalah yang dihadapi oleh sekolah dan menjadi prioritas pengabdian adalah terhadap pemahaman dan kesadaran pentingnya menggunakan masker yang baik dan benar oleh masyarakat desa Gelanggang. Hasil dari identifikasi masalah ini yang kemudian dilakukan tindak lanjut untuk mempersiapkan bentuk pelatihan bagi peserta yang ada.

Persiapan

Persiapan bentuk kegiatan disesuaikan dengan hasil identifikasi masalah yang dihadapi mitra agar kegiatan yang diberikan tepat dan sesuai dengan masalah yang dihadapi. Berdasarkan hasil idenfikasi masalah tersebut di atas, maka bentuk kegiatan yang dipersiapkan, yaitu: 1) Ceramah tentang bahayanya ancaman covid-19 yang dapat merenggut korban jiwa kepada siapa saja yang terserang virus 2) memberikan pemahaman dan pengetahuan mengenai langkah protokol kesehatan yang perlu dilakukan salah satunya adalah menggunakan masker yang baik dan benar. 3) Monitoring dan evaluasi terhadap kegiatan. Dalam persiapan kegiatan ini, semua yang dibutuhkan dalam kegiatan disiapkan baik materi dan modul ceramah dan diskusi, bahkan perlengkapan yang dibutuhkan dalam ceramah dan pendampingan dan monitoring dan evaluasi.

Pelaksanaan

Pelaksanaan kegiatan dilakukan secara marathon dan langsung menemui warga masyarakat yang layak membutuhkan bantuan masker secara gratis. Kegiatan dilakukan sambil berdiskusi dan mengedukasi masyarakat terkait covid-19 dan protokol kesehatan berupa penggunaan masker yang baik dan benar kemudian diakhiri dengan pembagian masker secara langsung kepada warga masyarakat yang ditemui. Dokumentasi kegiatan tergambar sebagai berikut: 


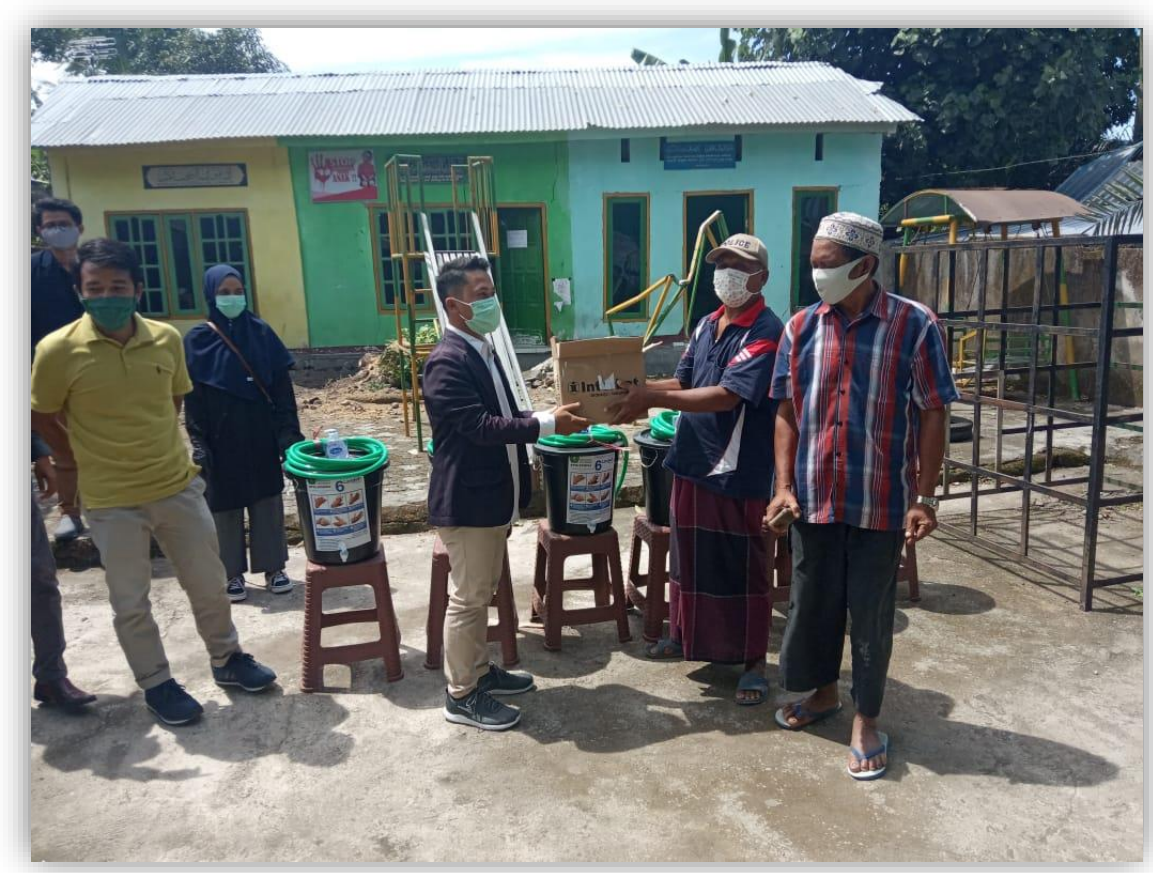

Gambar 1. Kegiatan Edukasi dan Penyuluhan Menggunakan Masker Yang Baik dan Benar Serta Pembagian Masker Gratis

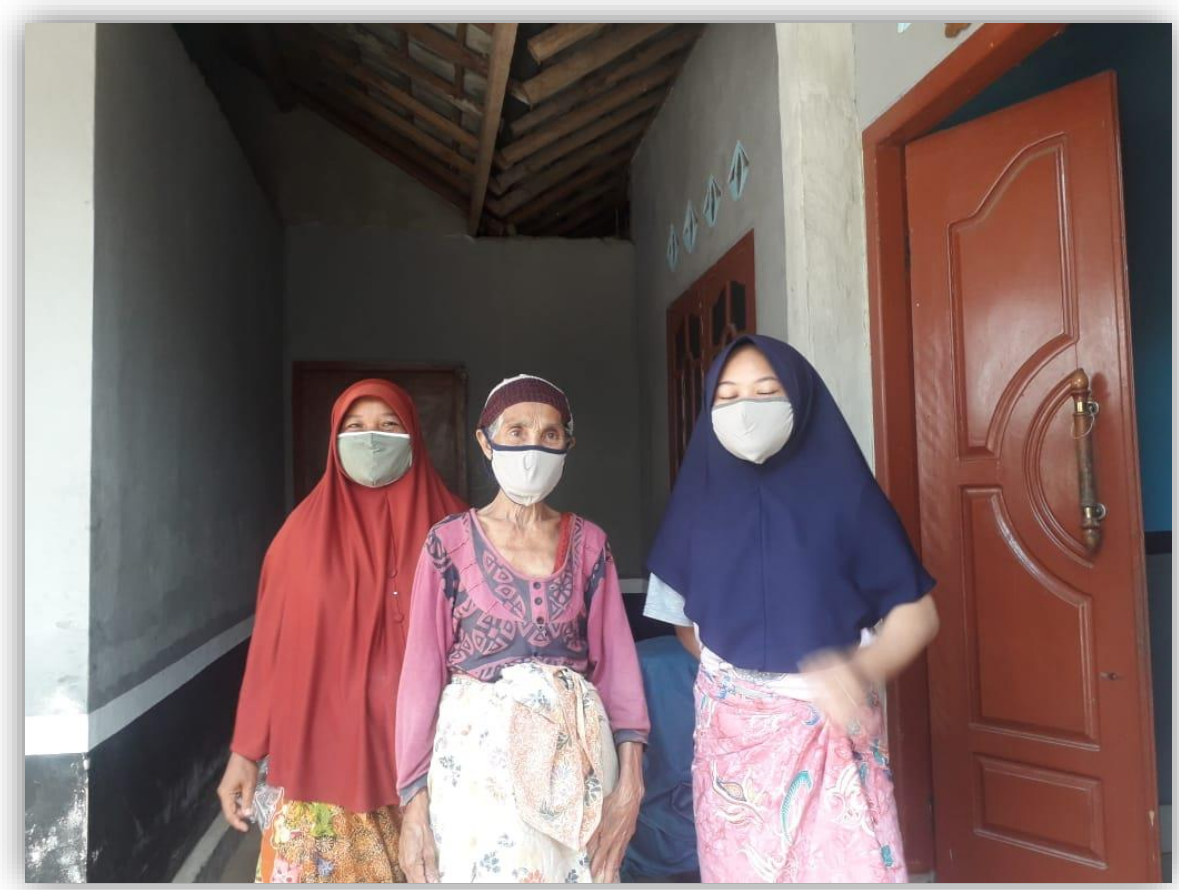

Gambar 2. Kegiatan Edukasi dan Penyuluhan Menggunakan Masker Yang Baik dan Benar Serta Pembagian Masker Gratis 


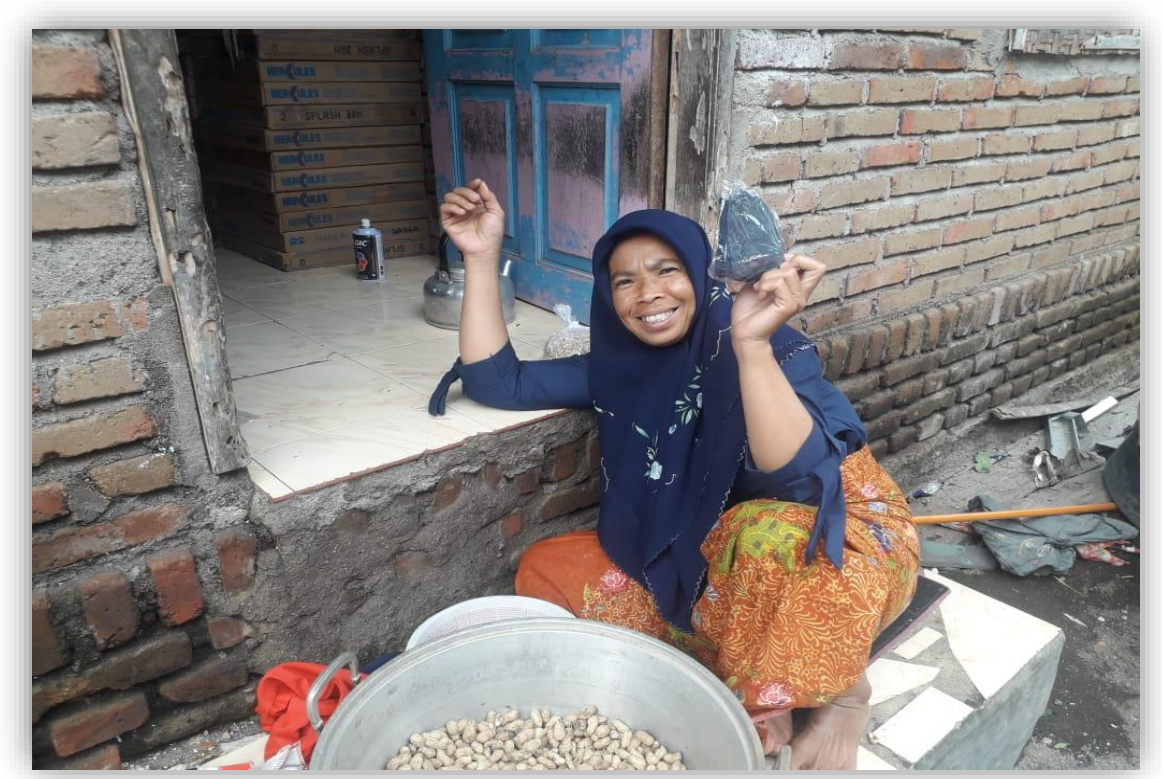

Gambar 3. Kegiatan Edukasi dan Penyuluhan Menggunakan Masker Yang Baik dan Benar Serta Pembagian Masker Gratis

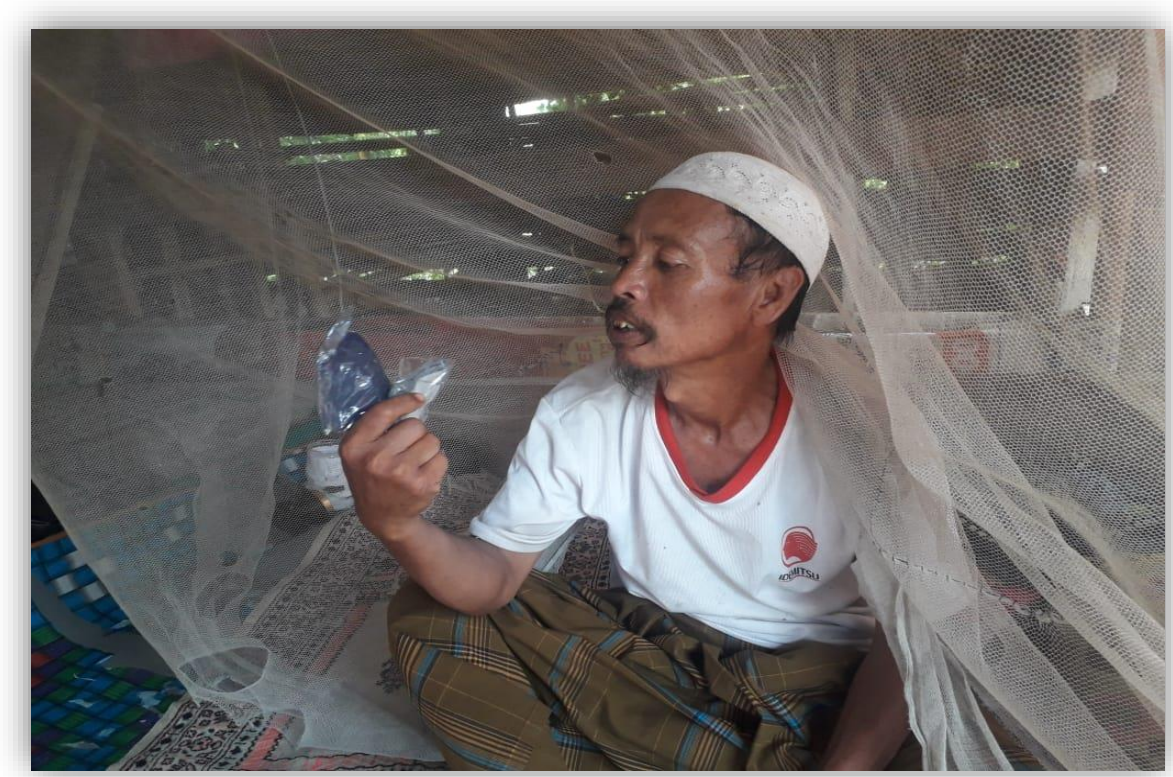

Gambar 4. Kegiatan Edukasi dan Penyuluhan Menggunakan Masker Yang Baik dan Benar Serta Pembagian Masker Gratis

\section{Evaluasi}

Monitoring dan evaluasi terhadap dampak dari kegiatan tersebut, dilakukan untuk mengetahui ketercapaian kegiatan yaitu meningkatnya pemahaman dan kesadaran masyarakat akan pentingnya mengetahui ancaman covid-19 dan pentingnya melaksanakan protokol kesehatan yakni menggunakan masker yang baik dan benar. Setelah kegiatan ini dilakukan, maka selanjutnya proses monitoring dan evaluasi dilakukan untuk melihat keefektifan kegiatan ini. Dari hasil monitoring dan evaluasi ini, diperoleh data bahwa masyarakat mulai terbiasa menerapkan protokol kesehatan dengan baik yaitu menggunakan masker dengan baik dan benar. Hasil dari kegiatan ini adalah meningkatnya pengetahuan dan kemampuan peserta tentang protokol kesehatan.

\section{KESIMPULAN}

Berdasarkan kegiatan pengabdian kepada masyarakat yang dilakukan, maka dapat disimpulkan bahwa: 1) Sebagian besar masyarakat di desa Gelanggang kecamatan Sakra 
Timur kabupaten Lombok Timur yang masih belum percaya sepenuhnya dengan ancaman covid-19 dapat mulai memahami bahaya dan ancaman dari covid-19. 2) Masyarakat yang masih abai dengan protokol kesehatan yang dianjurkan oleh pemerintah mulai mematuhi protokol kesehatan yang berlaku. 3) Pembagian masker yang dilakukan sangat membantu masyarakat dalam memperoleh masker yang sesuai standar dikarenakan kelangkaan yang terjadi.

\section{DAFTAR PUSTAKA}

Agustina, B. (2016). Kewenangan Pemerintah Dalam Perlindungan Hukum Pelayanan Kesehatan Tradisional Ditinjau Dari Undang-Undang Republik Indonesia Nomor 36 Tahun 2009 Tentang Kesehatan. Jurnal Wawasan Yuridika, 32(1), 82-98.

Greenhalgh, T., Schmid, M. B., Czypionka, T., Bassler, D., \& Gruer, L. (2020). Face masks for the public during the covid-19 crisis. Bmj, 369 .

https://corona.ntbprov.go.id/ dinaskesehatanNTB. (diakses tanggal 3 Juli 2021).

Heldavidson, "First Covid-19 Case Happened in November, China Government Records Show 2020", -Report diakses dari https://www.theguardian.com/world/2020/mar/13/first-covid-19-case-happened-innovember-china-government-records-show-report. (Diakses tanggal 20 Juni 2021).

Kementerian Kesehatan RI. 2020. Frequently Asked Questions (FAQ) COVID-19. http://Covid19.kemekes.go.id./

Lim, C. Y., Bohn, M. K., Lippi, G., Ferrari, M., Loh, T. P., Yuen, K. Y., ... \& Horvath, A. R. (2020). Staff rostering, split team arrangement, social distancing (physical distancing) and use of personal protective equipment to minimize risk of workplace transmission during the COVID-19 pandemic: A simulation study. Clinical biochemistry, 86, 15-22.

Marzuki, I., Bachtiar, E., Zuhriyatun, F., Purba, A. M. V., Kurniasih, H., Purba, D. H., \& Airlangga, E. (2021). COVID-19: Seribu Satu Wajah. Yayasan Kita Menulis.

Sembiring, R., \& Suryani, D. E. (2020). Sosialisasi Penerapan Protokol Kesehatan di Masa Pandemi Dengan Pembagian Masker Kesehatan Kepada Para Pedagang dan Pengunjung Pasar Tradisional Pajak Sore Padang Bulan. Jurnal Abdimas Mutiara, 1(2), 124-130.

Sii, P., Iku, P. F., Warung, Y. E., Danu, A. K., \& Nesi, A. (2020). Wujud Kepedulian Melawan Covid-19 Melalui Kegiatan Pembagian 5.000 Masker Dan Hand Sanitizer Kepada Masyarakat Di Pasar Puni Ruteng-Manggarai. Randang Tana: Jurnal Pengabdian Masyarakat, 3(2), 93-99.

Suhartati, R., Mardiana, U., \& Nurpalah, R. (2020). Pemberdayaan Masyarakat Dalam Penggunaan Hand Sanitizier dan Masker Sebagai Upaya Preventif Terhadap Covid19. BANTENESE: JURNAL PENGABDIAN MASYARAKAT, 2(1), 26-33.

Utami, N. K. Y. (2020). GERAKAN 1000 MASKER: PEMBAGIAN MASKER KEPADA YAYASAN KAKAK ASUH BALI KARANGASEM. Jurnal Lentera Widya, 1(2), $8-13$.

World Health Organization, "Coronavirus disease (COVID-19) outbreak", https://www.who.int/westernpacific/emergencies/covid-19, (diakses pada 1 Juli 2021). 